\title{
KLASIFIKASI PRIORITAS DISTRIK TERHADAP KETAHANAN PANGAN MENGGUNAKAN METODE JARINGAN SYARAF TIRUAN
}

\author{
Agusta Praba Ristadi Pinem ${ }^{1}$, Nurtriana Hidayati² ${ }^{2}$ Kholidin $^{3}$ \\ 1,2,3Program Studi Sistem Informasi \\ Fakultas Teknologi Informasi dan Komunikasi \\ Universitas Semarang \\ Email : agusta.pinem@usm.ac.id ${ }^{1}$, anna@usm.ac.id ${ }^{2}$,kholidin@gmail.com ${ }^{3}$
}

\begin{abstract}
ABSTRAK
Isu ketahanan pangan sangat erat dengan program swasembada yang dicanangkan. Pemerintah telah melakukan pemetaaan ketahanan dan kerentanan pangan yang dirinci hingga per distrik (kelurahan) dan kecamatan. Peta ketahanan pangan mengelompokan atau mengklasifikasi distrik berdasarkan prioritas ketahanan pangan. Prioritas ketahanan pangan menjadi informasi untuk mendukung proses pengambilan keputusan. Proses klasifikasi dapat juga dilakukan dengan salah satu metode data mining yaitu menggunakan metode Jaringan Syaraf Tiruan (JST). JST adalah salah satu metode klasifikasi yang memungkinkan jaringan untuk mengolah data sebagai pembelajaran dari training dataset. Dalam penelitian ini JST digunakan untuk mengklasifikasi prioritas distrik terhadap ketahanan pangan sehingga dapat diketahui distrik yang mengalamai kerentanan pangan sebelum berubah menjadi distrik yang rawan pangan. Dataset yang digunakan adalah ketahanan dan kerentanan pangan Provinsi Papua Barat. Output klasifikasi JST dibandingkan dengan data real menghasilkan nilai korelasi Spearman sebesar 0,9375 yang menunjukan bahwa metode JST mampu melakukan klasifikasi prioritas ketahanan pangan dan kerentanan pangan dengan menggunakan 10 indikator.
\end{abstract}

Kata Kunci: Jaringan Syaraf Tiruan, JST, Ketahanan Pangan, Klasifikasi

\begin{abstract}
The issue of food security is closely linked to the self-sufficiency program proclaimed. The government has conducted food security and vulnerability mapping detailing up to the urban village and sub-district. The food security atlas classifies districts based on food security priorities. The priority of food security becomes information to support the decision-making process. Classification process can also be done with one method of data mining i.e. Artificial Neural Network (ANN). ANN is one of the classification methods that enable the network to learn from the training dataset. In this research, ANN uses to classify district priorities on food security so can be known which districts are experiencing food vulnerability before turning into food-insecure
\end{abstract}


districts. The dataset used is the resistance and vulnerability of West Papua Province. Output classification of ANN compared with real data with result Spearman correlation value 0.9375 which shows that the ANN method can classify the priority of food security and food vulnerability by using 10 indicators.

Keywords: Artificial Neural Network, ANN, Food Security, Classification

\section{PENDAHULUAN}

Salah satu misi Presiden Jokowi pada masa pemerintahannya adalah swasembada pangan. Swasembada pangan sendiri adalah suatu negara dapat menghasilkan pangan sendiri dan memenuhi tingkat konsumsi penduduknya. Hal ini ditunjukan dengan pembangunan embung dan peningkatan produk pangan melalui rekayasa dibidang pertanian. Bidang pangan merupakan isu strategis yang dapat berdampak pada sektor lain. Pemerintah juga melakukan pemetaaan ketahanan dan kerentanan pangan seluruh daerah di Indonesia yang menggambarkan kondisi ketahanan dan kerentangan pangan. Batas administrasi yang digunakan dirinci hingga per distrik atau kecamatan. Indikator-indikator yang digunakan dalam penentuan ketahanan dan kerentanana pangan yaitu terdiri dari 3 aspek ketahanan pangan, yaitu ketersediaan bahan pangan, akses atau fasilitas pendukung ke pangan dan pemanfaatan pangan (DKKP, 2015). Indikatorindikator tersebut digunakan sebagai parameter untuk mengelompokan distrik kedalam prioritas-prioritas ketahanan pangan.

Provinsi Papua adalah salah satu provinsi yang disorot terkait ketahanan pangan. Hal ini disebabkan oleh kejadian rawan pangan yang pernah melanda daerah Papua. Provinsi Papua terdiri dari 156 distrik atau kecamatan dan membutuhkan 10 indikator untuk mengelompokan ketahanan pangan. Besarnya data yang digunakan pada peta ketahanan dan kerentanan pangan dapat diaplikasikan pada Data Mining. Data Mining mengakomodir proses klasifikasi dengan banyak variable dan jumlah data yang besar untuk mengesktrak data sehingga memperoleh pengetahuan (Maharani, 2015). Pengetahuan tersebut selanjutnya digunakan untuk memprediksi berdasarkan varibel yang digunakan 
sebelumnya. Salah satu metode yang dapat digunakan untuk proses klasifikasi dan prediksi adalah Jaringan Syaraf Tiruan (JST) (Fitri et al., 2014).

Beberapa penelitian telah memanfaatkan metode JST untuk prediksi maupun klasifikasi diberbagai bidang. Pada penelitian sebelumnya metode JST digunakan untuk klasifikasi kualitas minuman beer (Dębska \& Guzowska-Świder, 2011), klasifikasi jaminan mutu makanan (Wang, Yue, \& Zhou, 2017) dan klasifikasi penyakit jantung (Jabbar et al., 2013). Sebagian besar penelitian menunjukan metode JST memiliki tingkat akurasi yang baik pada proses klasifikasi. Selain itu JST juga digunakan untuk proses prediksi. Penelitian terdahulu untuk predikis konsumsi energi pada bangunan gedung (Ruiz et al., 2018). Hal ini menunjukan JST memiliki kemampuan adaptive terhadap macammacam dataset dengan menghasilkan akurasi yang baik.

Kemampuan metode JST dalam proses klasifikasi menjadi latar belakang penelitian ini untuk klasifikasi prioritas ketahanan pangan. Hasil analisa dapat digunakan untuk memprediksi tingkat ketahanan pangan suatu daerah sebelum daerah tersebut mengalami kerentanan pangan. Penentuan prioritas ketahanan pangan yang memiliki 10 indikator atau variabel menentukan akurasi metode JST dalam bidang pangan.

\section{METODE PENELITIAN}

\section{Data Mining}

Data Mining merupakan suatu bidang keilmuan yang mengekstrak informasi yang penting dari data yang besar. Mempelajari pola pada data untuk menghasilkan pengetahuan baru (Fitri et al., 2014). Pola-pola ini dapat membantu dalam pengambilan keputusan di waktu yang akan datang. Salah satu teknik dalam data mining adalah klasifikasi. Klasifikasi adalah proses penentuan kelompok atau kelas sebuah data baru pada beberapa kategori atau kelas yang digunakan sebagai target (Fitri et al., 2014). Klasifikasi mengidentifikasi objek dengan mengelompokkannya menjadi salah satu rangkaian kelas yang terbatas, yang melibatkan perbandingan fitur terukur 
dari objek baru dengan objek yang diketahui atau kriteria lain yang diketahui dan menentukan apakah objek baru termasuk dalam kategori objek tertentu (Dębska \& Guzowska-Świder, 2011).

Klasifikasi termasuk pada pembelajaran jenis supervised learning, yaitu adalah sebuah model dimana terdapat data yang dilatih dan terdapat variable atau label yang digunakan sebagai target sehingga ditujukan untuk mengkelompokan suatu data ke data atau kelas yang ada (Darujati \& Gumelar, 2012). Pada supervised learning, data latihan mengandung pasangan data input dan output yang diharapkan. JST bertindak sebagai algoritma pemecahan masalah yang dapat melakukan pemetaan, regresi, pemodelan, clustering, klasifikasi dan analisis data multivarian (Dębska \& Guzowska-Świder, 2011).

\section{Jaringan Syaraf Tiruan (JST)}

Metode JST adalah model matematis yang didasarkan pada jaringan saraf, yaitu jaringan syaraf pada otak manusia (Jabbar et al., 2013). JST secara tradisional terdiri dari simpul (atau neuron) dalam tiga lapisan atau lebih (Jabbar et al., 2013). JST merupakan penggambaran secara umum jaringan syaraf menjadi model matematika sebagai berikut

a. Pengolahan dan pemroresan data pada neurons.

b. Sinyal data ditransimisikan melalui neuron-neuron lewat penghubung antar jaringan.

c. Penghubung antar neuron mempunyai bobot yang akan meningkatkan atau melemahkan sinyal data.

Untuk menghasilkan output, masing-masing neuron menggunakan fungsi pengolahan yang berjalan pada penjumlahan input yang diterima. Nilai output kemudian dibandingkan dengan threshold (Wang et al., 2017). Informasi yang menjadi dasar dalam pengoperasian JST diperoleh dari Neuron yang bertindak sebagai sel atau unit terkecil. Sinyal dari input neuron akan diteruskan ke neuron lain atau tidak tergantung dari fungsi aktivasi didalam penghubung. 


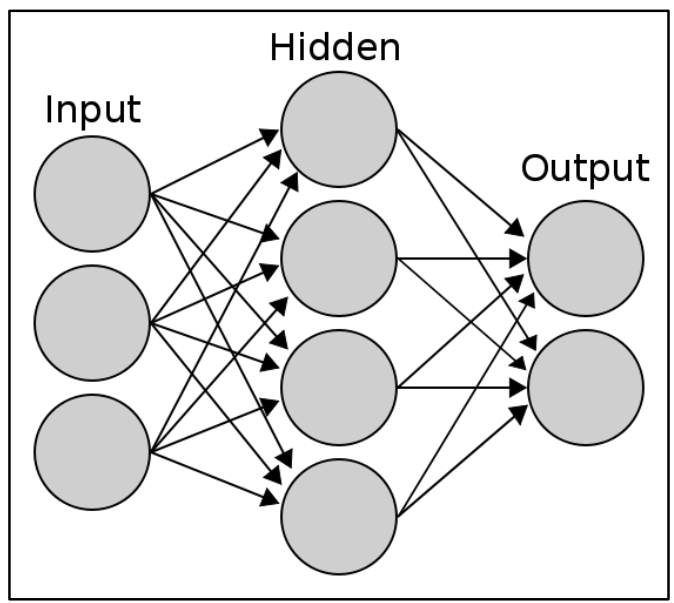

Gambar 1. Diagram jaringan saraf tiruan

Diagram jaringan syaraf pada gambar 1 mereferensi pada banyak lapisan (multilayer) (Jabbar et al., 2013). Secara umum layer tersebut terdiri dari tiga yaitu yang ditunjukan pada gambar 1:

a. Lapisan masukan (input)

b. Lapisan tengah (hidden )

c. Lapisan keluaran (output) (Wang et al., 2017).

Ketika merancang JST ada beberapa aspek yang harus dipertimbangkan diantaranya: lapisan jaringan, jumlah neuron pada tiap-tiap lapisan, titik (node) pada lapisan masukan dan keluaran sebaik pada saat fungsi aktivasi, inisialisasi nilai awal, kecepatan pembelajaran (Paradarami et al., 2017).

Backpropagation adalah metode yang digunakan dalam JST untuk menghitung gradien yang diperlukan dalam perhitungan bobot yang akan digunakan dalam jaringan untuk pelatihan multilayer (Wang et al., 2017). Metode backpropagation termasuk dalam model supervised learning, yaitu proses pelatihan data dengan labet atau target yang telah ditentukan. Pola masukan dan pola yang diharapakan kemudian dimasukan ke jaringan penghubung sehingga diperoleh perbedaan pola. Perbedaan pola keluaran dan pola yang diinginkan diperkecil melalu proses pengubahan nilai bobot pada jaringan. Latihan dilakukan secara iterasi sehingga semua pola yang dihasilkan jaringan sesuai dengan pola yang diinginkan (Sampurno \& Seminar, 2017). 


$$
r_{s}=1-\frac{6 \sum d_{i^{2}}}{n\left(n^{2}-1\right)}
$$

Keterangan :

$$
\begin{aligned}
r_{s} & =\text { Koefisien Korelasi Spearman } \\
d_{i} & =\text { Selisih tiap rangking } \\
n & =\text { Banyaknya data }
\end{aligned}
$$

Pengujian menggunakan korelasi Spearman atau persamaan 1 untuk memperoleh akurasi metode JST Backpropagation dalam klasifikasi tingkat ketahanan pangan. Pengujian dilakukan dengan cara membandingkan hasil klasifikasi prioritas yang dihasilkan metode JST dengan data real yang telah dikeluarkan DKKP dan mencari nilai korelasi Spearman, MAE, MSE dan RMSE.

\section{Ketahanan dan Kerentanan Pangan}

Ketahanan pangan adalah keadaan dimana semua orang dapat memenuhi kebutuhan pangan, mempunyai akses pangan dan mempunyai kemampuan untuk memilih makanan yang sehat secara fisik, social dan ekonomi (BKP, 2011). Indikator-indikator yang digunakan dalam penentuan ketahanan dan kerentanana pangan terdiri dari 3 aspek utama, yaitu ketersediaan pangan, akses ke pangan dan pemanfaatan pangan (DKKP, 2015). Indikator yang digunakan melingkupi hasil produksi serealia, infrastruktur, kesehatan dan penduduk. Berikut 10 indikator yang digunakan sebagai variable dalam penelitian.

Tabel 1 Indikator ketahanan dan kerentanan pangan Papua (DKKP, 2015).

\begin{tabular}{|l|l|l|}
\hline No & Aspek & \multicolumn{1}{c|}{ Indikator } \\
\hline 1 & \multirow{2}{*}{$\begin{array}{c}\text { Ketersediaan } \\
\text { Pangan }\end{array}$} & $\begin{array}{l}\text { Rasio konsumsi normatif per kapita terhadap ketersediaan bersih } \\
\text { bahan pangan atau serealia. }\end{array}$ \\
\hline 2 & \multirow{2}{*}{ Akses Pangan } & Persentase penduduk yang berada di bawah garis kemiskinan \\
3 & & Persentase desa dengan akses penghubung yang kurang memadai \\
& & Persentase rumah tangga tanpa akses listrik \\
\hline 4 & \multirow{2}{*}{$\begin{array}{c}\text { Pemanfaatan } \\
\text { Pangan }\end{array}$} & Perempuan buta huruf \\
& & Persentase rumah tangga tanpa akses ke air bersih \\
& & $\begin{array}{l}\text { Persentase desa dengan jarak lebih dari 5 km dari fasilitas } \\
\text { kesehatan }\end{array}$ \\
\hline 8 & \multirow{2}{*}{$\begin{array}{c}\text { Gizi dan Dampak } \\
\text { Kesehatan }\end{array}$} & Tinggi badan balita di bawah standar (stunting) \\
& Angka harapan hidup pada saat lahir \\
\hline 9 & Penduduk & Jumlah penduduk \\
\hline 10 & &
\end{tabular}


Tabel 1 merupakan 10 indikator yang digunakan dalam penentuan prioritas, terdiri dari 3 aspek yaitu ketersediaan pangan, akses pangan, pemanfaatan pangan, gizi dan dampak kesehatan dan aspek penduduk. Dataset yang digunakan adalah data dari peta ketahanan dan kerentanan pangan provinsi Papua Barat yang terdiri dari 156 distrik atau kecamatan. Kemudian pada penelitian ini menggunakan perbandingan $70 \%$ data training dan $30 \%$ data test (Gholami et al., 2015). Dalam proses pelatihan dan pengujian data di data mining, secara ideal menggunakan $70 \%$ data sebagai data training dan $30 \%$ data testing untuk mengurangi waktu proses komputasi (Gholami et al., 2015). Perbandingan pemecahan data yang digunakan yaitu 109 distrik beserta 10 indikator digunakan sebagai data training sedangkan 47 distrik beserta 10 indikator sisanya sebagai data pengujian. Setiap distrik akan dipertimbangkan berdasarkan kabupaten, untuk meratakan keberagaman data.

109 data training dilakukan pembelajaran dengan metode JST dan ditentukan masing-masing target atau output yang diharapkan. Masingmasing data diberikan target berdasarkan hasil prioritas yang dikeluarkan oleh DKKP. Nilai prioritas diberi skala 1 hingga 5. Proses training ini menghasilkan suatu pola yang dipelajari JST berdasarkan data training dan target sehingga dapat digunakan untuk mengklasifikasikan distrik lain.

\section{HASIL DAN PEMBAHASAN}

\section{Data Training dan Data Testing}

Data training dan data testing yang digunakan menggunakan perbandingan 70\% dan 30\% dari keseluruhan data (Gholami et al., 2015). Perbandingan pemecahan data yang digunakan yaitu 109 distrik beserta 10 indikator digunakan sebagai data training. 109 data dipilih untuk dilakukan training pada perangkat lunak Matlab dengan metode JST melalui bantuan nntool sebagai variable input pelatihan. Sedangkan data testing yang digunakan adalah 47 data distrik yang diambil dari setiap Kabupaten atau Kota di Provinsi Papua Barat dengan melihat keanekaragaman distrik. Karena 
masing-masing distrik memiliki karakteristik nilai indikator yang variatif. 10 indikator pada 47 distrik dinputkan pada Matlab sebagai variable input pengujian.

\section{Pengujian dan Akurasi}

Proses pelatihan variable yang digunakan yaitu variable input pelatihan dan variable target. Sedangkan dalam pengujian menggunakan variable input pengujian dan tanpa menggunakan data target. Output yang dihasilkan kemudian dibandingkan dengan data real yang dikeluarkan DKKP.

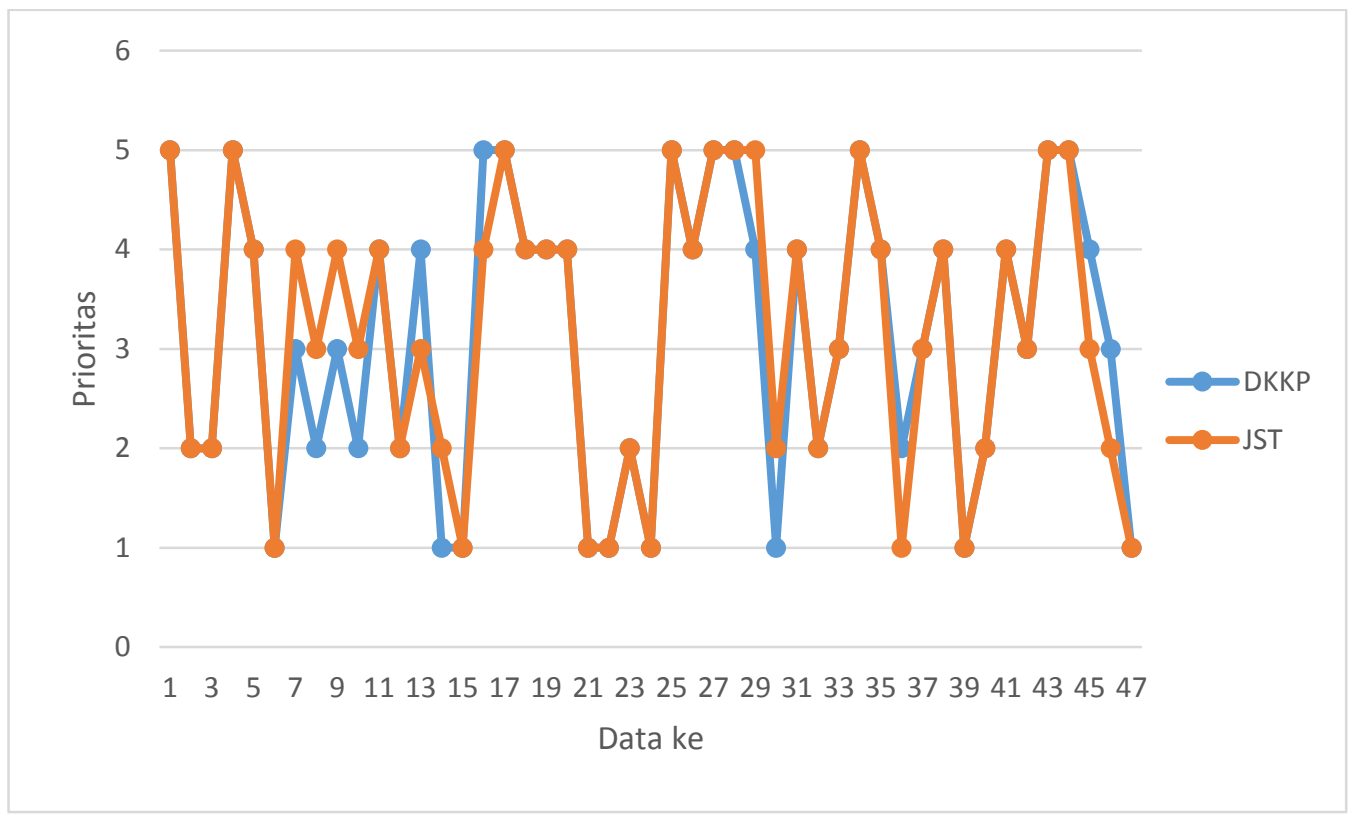

Gambar 2. Grafik hasil pengujian

Gambar 2 adalah hasil pengujian dari metode JST dengan dataset ketahanan dan keretanan pangan Provinsi Papua Barat pada tahun 2018. Hasil output data testing dari metode JST yang terdiri dari 47. Hasil JST prediksi menunjukan 35 distrik atau data menghasilkan output yang sesuai dengan data real. Sedangkan 12 data masih belum tepat.

Tabel 2 Hasil Pengujian

\begin{tabular}{|l|l|l|l|l|l|l|l|l|}
\hline Data ke & 1 & 2 & 3 & 4 & $\ldots$ & 107 & 108 & 109 \\
\hline PRIORITAS & 5 & 2 & 2 & 5 & $\ldots$ & 4 & 3 & 1 \\
\hline JST & 5 & 2 & 2 & 5 & $\ldots$ & 3 & 2 & 1 \\
\hline
\end{tabular}

\begin{tabular}{|l|l|l|}
\hline Korelasi & $=$ & 0.9375 \\
\hline
\end{tabular}




\begin{tabular}{|l|l|l|}
\hline Spearman & & \\
\hline MAE & $=$ & 0.2553 \\
\hline MSE & $=$ & 0.2553 \\
\hline RMSE & $=$ & 0.5053 \\
\hline
\end{tabular}

Dalam menghitung akurasi selain menggunakan Mean Absolute Error (MAE), Mean Squared Error (MSE) dan Root Mean Squared Error (RMSE), digunakan juga Korelasi Spearman (persamaan 1) untuk menghitung korelasi hasil klasifikasi JST dengan data real. Nilai MAE, MSE dan RMSE ditunjukan pada tabel 2. Nilai korelasi Spearman yang dihasilkan adalah 0.9375, dimana semakin dekat dengan nilai 1 , maka semakin besar pula nilai korelasi. Yang berarti motede JST dalam mengklasifikasikan tingkat prioritas ketahanan dan kerentanan pangan memiliki nilai error yang kecil. Semakin besar nilai korelasi semakin besar tingkat akurasi suatu metode. Nilai korelasi biasa digunakan dalam kasus perangkingan dan klasifikasi, namun jarang digunakan dalam kasus prediksi.

\section{KESIMPULAN DAN SARAN}

Kesimpulan dari penelitian ini adalah telah terbentuknya sebuah model klasifikasi penentuan prioritas ketahanan dan kerentanan pangan Provinsi Papua Barat dengan menggunakan metode Jaringan Syaraf Tiruan. Hasil dari model klasifikasi telah diuji dan divalidasi, dengan hasil menunjukan bahwa model klasifikasi menghasilkan output dengan nilai korelasi Spearman sebesar 0,9375. Semakin mendekati nilai 1 , maka semakin baik pula tingkat validasi sebuah metode.

Adapun saran yang diberikan oleh penulis untuk pengembangan penelitian selanjutnya adalah:

1. Pengembangan model klasifikasi penentuan prioritas ketahanan dan kerentanan pangan Provinsi Papua Barat dengan berbasis web.

2. Perlu adanya perbandingan metode Jaringan Syaraf Tiruan dengan metode lainnya yang mendukung proses klasifikasi prioritas dalam bidang ketahanan pangan. 


\section{DAFTAR PUSTAKA}

BKP. (2011). Peta Ketahanan dan Kerentanan Pangan Jawa Tengah 2010. Badan Ketahanan Pangan Provinsi Jawa Tengah.

Darujati, C., \& Gumelar, A. B. (2012). Pemanfaatan Teknik Supervised Untuk Klasifikasi Teks Bahasa Indonesia. Jurnal Bandung Text Mining, 16(1), 51.

Dębska, B., \& Guzowska-Świder, B. (2011). Application of artificial neural network in food classification. Analytica Chimica Acta, 705(1-2), 283291. https://doi.org/10.1016/j.aca.2011.06.033

DKKP. (2015). Peta Ketahanan dan Kerentanan Pangan (Food Security and Vulnerability Atlas/FSVA) untuk Provinsi Papua pada tahun 2015. Dewan Ketahanan Pangan Provinsi Papua.

Fitri, F., Setyawati, O., \& Rahadi, D. (2014). Aplikasi Jaringan Syaraf Tiruan Untuk Penentuan Status Gizi Balita Dan Rekomendasi Menu Makanan Yang Dibutuhkan. Jurnal EECCIS, 7(2), 119-124.

Gholami, V., Chau, K. W., Fadaee, F., Torkaman, J., \& Ghaffari, A. (2015). Modeling of groundwater level fluctuations using dendrochronology in alluvial aquifers. Journal of Hydrology, 529, 1060-1069. https://doi.org/10.1016/j.jhydrol.2015.09.028

Jabbar, M. A., Deekshatulu, B. L., \& Chandra, P. (2013). Classification of heart disease using artificial neural network and feature subset selection. Global Journal of Computer Science and Technology Neural \& Artificial Intelligence, 13(3).

Maharani, W. (2015). Klasifikasi Data Menggunakan JST Backpropagation Momentum dengan Adaptive Learning Rate. In Seminar Nasional Informatika (SEMNASIF) (Vol. 1).

Paradarami, T. K., Bastian, N. D., \& Wightman, J. L. (2017). A hybrid recommender system using artificial neural networks. Expert Systems with Applications, 83, 300-313. https://doi.org/10.1016/j.eswa.2017.04.046

Ruiz, L. G. B., Rueda, R., Cuéllar, M. P., \& Pegalajar, M. C. (2018). Energy consumption forecasting based on Elman neural networks with evolutive 
optimization. Expert Systems with Applications, 92, 380-389. https://doi.org/10.1016/j.eswa.2017.09.059

Sampurno, R. M., \& Seminar, K. B. (2017). Application of Artificial Neural Network in the Early Warning System for Food Crisis Management. Jurnal Teknotan, 11(1). https://doi.org/10.24198/jt.vol11n1.8

Wang, J., Yue, H., \& Zhou, Z. (2017). An improved traceability system for food quality assurance and evaluation based on fuzzy classification and neural $\begin{array}{llll}\text { network. } & \text { Food } & \text { Control, } & \text { 39, }\end{array}$ https://doi.org/10.1016/j.foodcont.2017.04.013 